\title{
Coxsackie B virus IgM in children at onset of Type 1 (insulin-dependent) diabetes mellitus: evidence for IgM induction by a recent or current infection
}

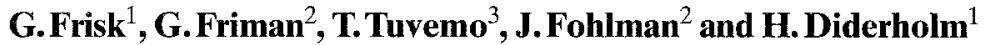 \\ ${ }^{1}$ Department of Medical Virology, Biomedical Centre, and the Departments of ${ }^{2}$ Infectious Diseases and \\ ${ }^{3}$ Paediatrics, University Hospital, University of Uppsala, Uppsala, Sweden
}

\begin{abstract}
Summary. Thirty-five children with newly-diagnosed Type 1 (insulin-dependent) diabetes mellitus and their 47 siblings were investigated for the presence of IgM antibodies to CoXsackie $B$ virus serotypes 1-5 (CBV 1-5) with the aid of $\mu$-antibody-capture radioimmunoassays. When a high cut-off value was used, $16(46 \%)$ diabetic children and $16(34 \%)$ siblings showed CBV-IgM. Of the siblings of diabetic patients positive for CBV-IgM, 11 (44\%) were CBV-IgM-positive; the corresponding figure for the siblings of negative patients was five $(26 \%)$. With a lower cut-off value, leading to a "borderline titre", the frequency of IgM positivity increased in both the patients and siblings. When the borderline titres were included, the number of IgM-positive patients was $19(54 \%)$ and the corresponding number of siblings was $29(62 \%)$. Of the siblings of positive patients, $27(93 \%)$ showed CBV-IgM, and of the siblings of the negative patients, two $(11 \%)$ were CBV-IgM-positive. Sixteen ( $89 \%$ ) siblings of IgM-negative patients remained negative. Regarding the serotypes of $\mathrm{CBV}$
\end{abstract}

to which IgM was directed, CBV 4 was most frequent, followed by serotypes CBV 3, CBV 2, CBV 5 and CBV 1 . There was a striking similarity between the individual diabetic child and his or her sibling(s) concerning this specificity of IgM. It is concluded that within most families with a newly-diagnosed diabetic child positive for CBV-IgM the same serotype(s) of the virus circulates and that the intrafamilial spread of virus is considerable. The results strongly indicate that the IgM detected was CBV-specific and caused by a recent or current CBV infection. It is highly probable that the same strain of virus was present in different members of the same family. Therefore, if diabetogenic CBV strains do in fact exist, additional factors must be of importance for the development of Type 1 diabetes in children infected with such a CBV strain but remaining non-diabetic.

Key words: Coxsackie virus, intrafamilial spread, diabetes mellitus, IgM, radioimmunoassay.
It has long been suggested that Coxsackie B viruses (CBV), especially serotype 4, may be of importance for the development of juvenile-onset Type 1 (insulin-dependent) diabetes mellitus. The seasonal distribution of $\mathrm{CBV}$ infections and the incidence rate of Type 1 diabetes have often been found to be similar [1,2]. More convincing evidence of CBV involvement has been provided by case reports. CBV 4 was isolated from the pancreas of a child who died a few days after the onset of Type 1 diabetes [3]. The pancreatic Beta cells showed necrosis, and there was a high titre of antibodies to CBV 4 in the serum. It was also found that the isolated virus was capable of inducing diabetes following inoculation into mice. In another fatal case of Type 1 diabetes, CBV 4 antigen was present in the Beta cells post-mortem and a high level of corresponding antibodies was found in the serum [4].

There have been a number of studies on the frequency of neutralizing antibodies to CBV in diabetic children [5].
In most of them a higher frequency of antibodies was observed in these patients than in control subjects, and in some cases an increase in titre was found after the onset of the disease. In recent years the presence of CBV-IgM has been studied in diabetic children with the aid of enzymelinked immunosorbent assays (ELISAs) and radioimmunoassays (RIAs). Using a $\mu$-antibody-capture ELISA, a significantly higher frequency of CBV-IgM was found in children with newly-diagnosed Type 1 diabetes than in control subjects $[6,7]$. With a $\mu$-antibody-capture RIA of IgM, we obtained similar results [8]. The question was raised as to whether the $\operatorname{IgM}$ was induced by a recent or current $\mathrm{CBV}$ infection rather than by cross-reacting antigens, endogenous or exogenous, or by unspecific polyclonal activation of IgM-secreting cells.

In the present work the occurrence of CBV-IgM both in children with Type 1 diabetes of recent onset and in their siblings was studied. The intrafamilial spread of CBV is considerable $[9,10]$ and if the CBV-IgM pattern is the 


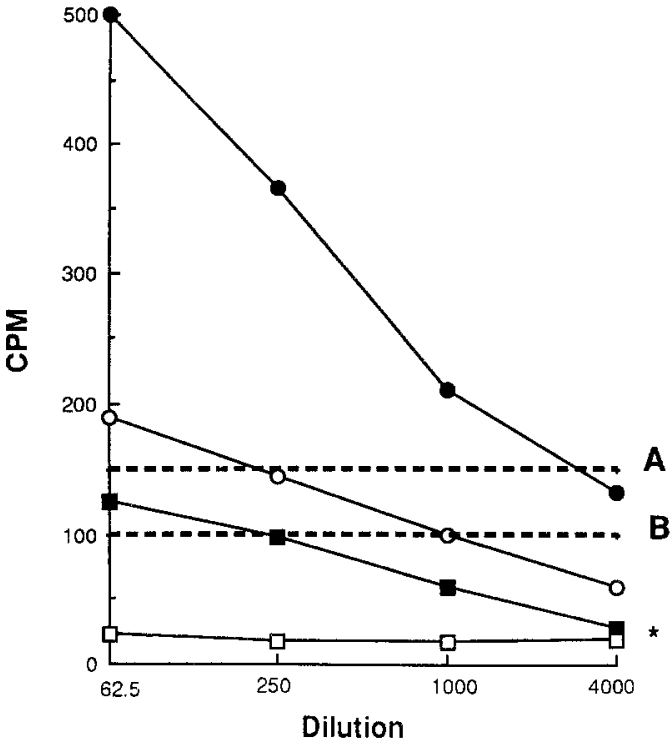

Fig.1. Radioimmunoassay (RIA) profiles of representative serum specimens. ( ) strongly positive serum; $(O)$ weakly positive serum; (ם) serum showing a borderline titre; ( $\square$ ) negative serum. *, Blank. A indicates the higher cut-off value at $150 \mathrm{cpm}$; B indicates the lower cut-off value at $100 \mathrm{cpm}$

same in the diabetic child as in his or her sibling(s), this would provide evidence for a recent or current $\mathrm{CBV}$ infection. In addition, the presence of IgM against diabetogenic strains of $\mathrm{CBV}$ (if such exist) in siblings remaining non-diabetic would indicate that other factors together with $\mathrm{CBV}$ are of importance for the development of Type 1 diabetes.

\section{Subjects and methods}

\section{Patients and their siblings}

Sera from 35 children from the County of Uppsala, $13(37 \%)$ boys and $22(63 \%)$ girls below the age of 15 years and diagnosed between 1983 and 1988 as having Type 1 diabetes, were studied. When Type 1 diabetes was suspected or confirmed, the children were immediately referred to the Department of Paediatrics, and the siblings to the Department of Infectious Diseases, Uppsala University Hospital. Sera were taken on the day of diagnosis (acute sera) and 2-3 months later (convalescent sera).

Sera from 47 siblings, $19(40 \%)$ boys and $28(60 \%)$ girls, aged 3 to 18 years were studied. The "acute" sera in this group were collected within 3 days to 6 weeks from the onset of Type 1 diabetes in the diabetic sibling. In some cases a second serum sample was taken after 2-3 months. In one child of the sibling group, only a convalescent serum was obtained. Twenty-seven of the diabetic children had one sibling, seven had two, and one had six.

\section{Antigens}

The strains of CBV used and the procedures for their propagation, labelling and purification have been previously described [11, 12]. Briefly, the viruses were propagated in a strain of Hela cells (JJH cells), and $\left.{ }^{[3} \mathrm{S}\right]$ methionine was used for the labelling. The viruses were purified by ultracentrifugation in $\mathrm{CsCl}$. The purity of the viruses was tested by sodium dodecyl sulphate-polyacrylamide gel electrophoresis (SDS-PAGE).

\section{RIA procedure}

A $\mu$-antibody-capture RIA was performed as previously described $[12,13]$. Briefly, polystyrene beads were coated with human- IgM$\mathrm{Fc}$-specific antibodies raised in rabbits (Jackson Immunoresearch Laboratories Inc, W. Baltimore, $\mathrm{Pa}$, USA). The diluted serum specimens were incubated with the coated beads for $2 \mathrm{~h}$ at $37^{\circ} \mathrm{C}$. The beads were then washed and ${ }^{35} \mathrm{~S}$-labelled virus was added. After incubation overnight, the beads were washed and the radioactivity was counted. The RIA results were expressed as reciprocal serum titres. The cut-off point used in the end-point calculations was three times the value of a buffer blank or negative sera, with the proviso that the cut-off value should be at least $150 \mathrm{cpm}$ (Fig. 1). The value of the buffer blank or the negative sera varied between 10 and $25 \mathrm{cpm}$. An additional cut-off point was also used; this was again three times the value of the buffer blank or the negative sera, but with the proviso that the cut-off value should be at least $100 \mathrm{cpm}$ (Fig.1). The titres obtained with this cut-off point are referred to as borderline titres.

\section{Results}

\section{$C B V$-IgM in Type 1 diabetic patients}

As seen in Tables 1 and 2, almost half of the Type 1 diabetic group, 16 of the 35 patients ( $46 \%$ ), showed a positive result with the higher cut-off value. In 13 patients monotypic IgM responses were found: in five of them there was an IgM response against CBV 4, in four against CBV 3, in three against CBV 2 and in one against CBV 5. There were also three patients with ditypic responses, two showing IgM against CBV 3 and CBV 4 and one with titres against CBV 4 and CBV 5. The titres varied between 62.5 and 8,000 , with a median value of 500 . When the lower cut-off value was used, resulting in a borderline titre, three more Type 1 diabetic patients became positive, two with IgM against CBV 4 alone and one against both CBV 4 and CBV 5 (Table 2). When the results with both the lower and higher cut-off were considered, the number of patients with ditypic responses increased to four. As seen in Table 1, there were also three patients with IgM against three serotypes and one with IgM against four serotypes.

\section{$C B V$-IgM in siblings}

Sixteen of the 47 siblings ( $34 \%$ ) showed CBV-IgM when the higher cut-off value was used (Tables 1,2). Of the 25 siblings of the 16 patients with definite IgM titres, 11 (44\%) were positive (Table 1). Seven siblings had monotypic IgM responses: three of these against $\mathrm{CBV} 4$, two against CBV 2, and two against CBV 3. Two siblings showed IgM against both $\mathrm{CBV} 3$ and $\mathrm{CBV} 4$, one against $\mathrm{CBV} 3$ and CBV 5, and one against CBV 4 and CBV 5. Of the 22 siblings of the diabetic patients showing borderline titres or lacking CBV-IgM, five (23\%) were positive; four of these had IgM against CBV 4 alone, and one against both CBV 2 and CBV 4 (Table 2). The titres varied between 62.5 and 
Table 1. IgM against Coxsackie B virus serotypes 1-5 (CBV 1-5) in siblings of patients with newly-diagnosed Type 1 (insulin-dependent) diabetes mellitus showing definite IgM titres against CBV

\begin{tabular}{|c|c|c|c|c|c|}
\hline \multirow{3}{*}{$\begin{array}{l}\text { Patients }^{a} \\
\text { and their } \\
\text { siblings }\end{array}$} & \multicolumn{5}{|c|}{ Serotype of CBV } \\
\hline & \multicolumn{2}{|c|}{ Definite titre } & \multicolumn{2}{|c|}{ Borderline titre } & \multirow{2}{*}{$\begin{array}{l}\text { Total IgM } \\
\text { positivity }\end{array}$} \\
\hline & $\mathrm{A}$ & $\mathrm{C}$ & $\mathrm{A}$ & $\mathrm{C}$ & \\
\hline $\begin{array}{l}\text { P1-6-F } \\
\text { S1-4-M }\end{array}$ & $\begin{array}{l}2 \\
2\end{array}$ & $\begin{array}{l}2 \\
\mathrm{NA}\end{array}$ & - & $\overline{\mathrm{NA}}$ & $\begin{array}{l}2 \\
2\end{array}$ \\
\hline $\begin{array}{l}\text { P2-8-F } \\
\text { S 1-6-F }\end{array}$ & $\begin{array}{l}2 \\
-\end{array}$ & $\begin{array}{l}2 \\
-\end{array}$ & - & $\frac{-}{2}$ & $\begin{array}{l}2 \\
2\end{array}$ \\
\hline $\begin{array}{l}\text { P } 3-15-M \\
\text { S1-16-M }\end{array}$ & $\begin{array}{l}2 \\
-\end{array}$ & $\stackrel{N A}{-}$ & $\frac{-}{2}$ & ${ }_{2}^{N A}$ & $\begin{array}{l}2 \\
2\end{array}$ \\
\hline $\begin{array}{l}\text { P 4-7-F } \\
\text { S1-15-F }\end{array}$ & $\begin{array}{l}3 \\
-\end{array}$ & 3 & - & - & $\begin{array}{l}3 \\
3\end{array}$ \\
\hline $\begin{array}{l}\text { P5-9-F } \\
\text { S1-12-M }\end{array}$ & $\begin{array}{l}3 \\
-\end{array}$ & $\begin{array}{l}3 \\
\mathrm{NA}\end{array}$ & $\begin{array}{l}5 \\
2,3\end{array}$ & $\begin{array}{l}5 \\
\mathrm{NA}\end{array}$ & $\begin{array}{l}3,5 \\
2,3\end{array}$ \\
\hline $\begin{array}{l}\text { P 6-12-M } \\
\text { S1-18-F } \\
\text { S2-17-F } \\
\text { S 3-16-M } \\
\text { S4-14-F } \\
\text { S 5-10-F } \\
\text { S6- 8-F }\end{array}$ & $\begin{array}{l}3 \\
- \\
- \\
- \\
- \\
- \\
3\end{array}$ & $\begin{array}{l}\text { NA } \\
\text { NA } \\
\text { NA } \\
\text { NA } \\
\text { NA } \\
\text { NA } \\
\text { NA }\end{array}$ & $\begin{array}{l}\overline{5} \\
3 \\
\overline{3} \\
3 \\
-4 \\
-\end{array}$ & $\begin{array}{l}\text { NA } \\
\text { NA } \\
\text { NA } \\
\text { NA } \\
\text { NA } \\
\text { NA } \\
\text { NA }\end{array}$ & $\begin{array}{l}3 \\
5 \\
3 \\
- \\
3,4 \\
3 \\
3\end{array}$ \\
\hline $\begin{array}{c}\text { P7-14-M } \\
\text { S1-M }\end{array}$ & $\begin{array}{l}3 \\
-\end{array}$ & $\begin{array}{l}\mathrm{NA} \\
\mathrm{NA}\end{array}$ & $\begin{array}{l}2 \\
5\end{array}$ & $\begin{array}{l}\text { NA } \\
\text { NA }\end{array}$ & $\begin{array}{l}2,3 \\
5\end{array}$ \\
\hline $\begin{array}{l}\text { P 8-10-M } \\
\text { S1-14-F } \\
\text { S2-6-F }\end{array}$ & $\begin{array}{l}3,4 \\
3,5 \\
3,4\end{array}$ & $\begin{array}{l}3,4 \\
3 \\
3,4\end{array}$ & $\begin{array}{l}1,5 \\
- \\
-\end{array}$ & $\begin{array}{l}-m \\
5 \\
-\end{array}$ & $\begin{array}{l}1,3,4,5 \\
3,5 \\
3,4\end{array}$ \\
\hline $\begin{array}{l}\text { P9-3-M } \\
\text { S1-9-M }\end{array}$ & $\begin{array}{l}3,4 \\
3\end{array}$ & $\begin{array}{l}\text { NA } \\
\text { NA }\end{array}$ & $\begin{array}{l}5 \\
-\end{array}$ & $\begin{array}{l}\text { NA } \\
\text { NA }\end{array}$ & $\begin{array}{l}3,4,5 \\
3\end{array}$ \\
\hline $\begin{array}{l}\text { P 10-10-F } \\
\text { S1-13-M }\end{array}$ & $\begin{array}{l}4 \\
4,5\end{array}$ & - & - & - & $\begin{array}{l}4 \\
4,5\end{array}$ \\
\hline $\begin{array}{r}\text { P11-12-M } \\
\text { S1-17-F } \\
\text { S2-8-F }\end{array}$ & $\begin{array}{l}4 \\
4 \\
2\end{array}$ & $\begin{array}{l}4 \\
\mathrm{NA} \\
\mathrm{NA}\end{array}$ & $\frac{-}{4}$ & $\begin{array}{l}\text { NA } \\
\text { NA }\end{array}$ & $\begin{array}{l}4 \\
4 \\
2,4\end{array}$ \\
\hline $\begin{array}{l}\text { P 12-9-M } \\
\text { S1-10-M } \\
\text { S2-M }\end{array}$ & $\begin{array}{l}4 \\
4 \\
4\end{array}$ & $\begin{array}{l}\mathrm{NA} \\
\mathrm{NA} \\
\mathrm{NA}\end{array}$ & $\begin{array}{l}- \\
- \\
-\end{array}$ & $\begin{array}{l}\text { NA } \\
\text { NA } \\
\text { NA }\end{array}$ & $\begin{array}{l}4 \\
4 \\
4\end{array}$ \\
\hline $\begin{array}{l}\text { P13-12-F } \\
\text { S 1-13-F }\end{array}$ & 4 & $\begin{array}{l}\mathrm{NA} \\
\mathrm{NA}\end{array}$ & $\begin{array}{l}2,3 \\
2,4\end{array}$ & $\begin{array}{l}\mathrm{NA} \\
\mathrm{NA}\end{array}$ & $\begin{array}{l}2,3,4 \\
2,4\end{array}$ \\
\hline $\begin{array}{c}\text { P14-14-M } \\
\text { S1-5-F } \\
\text { S2-6-F }\end{array}$ & $\begin{array}{l}4 \\
\overline{3}, 4\end{array}$ & $\begin{array}{l}\text { NA } \\
- \\
-\end{array}$ & $\begin{array}{l}3 \\
3 \\
-\end{array}$ & $\begin{array}{l}\text { NA } \\
3,4 \\
3\end{array}$ & $\begin{array}{l}3,4 \\
3,4 \\
3,4\end{array}$ \\
\hline $\begin{array}{c}\text { P } 15-11-F \\
\text { S1-M }\end{array}$ & 4,5 & $\begin{array}{l}\mathrm{NA} \\
\mathrm{NA}\end{array}$ & $\begin{array}{l}2 \\
2\end{array}$ & $\begin{array}{l}\mathrm{NA} \\
\mathrm{NA}\end{array}$ & $\begin{array}{l}2,4,5 \\
2\end{array}$ \\
\hline $\begin{array}{l}\text { P 16-4-F } \\
\text { S1-9-M } \\
\end{array}$ & $\begin{array}{c}5 \\
- \\
\end{array}$ & $\begin{array}{l}5 \\
\mathrm{NA}\end{array}$ & - & $\overline{\mathrm{NA}}$ & 5 \\
\hline
\end{tabular}

$A$, acute specimen; $C$, convalescent specimen; $N A$, specimen not available; $M$, male; $F$, female; $P$, patient; $S$, sibling.

a The first numeral indicates the patient number and the second one, age.

The first numeral indicates the sibling number and the second, age.

4,000 , with a median value of 500 . When the borderline titres were included, the CBV-IgM positivity rose noticeably. Of all 47 siblings, a positive result was now found in 29 $(62 \%)$, and $27(93 \%)$ of the 29 siblings of Type 1 diabetic children with IgM titres became positive (Tables 1,2). Sixteen $(89 \%)$ siblings of IgM-negative patients remained negative. When the results of both the lower and higher cut-
Table 2. IgM against Coxsackie $B$ virus serotypes 1-5 (CBV 1-5) in siblings (S) of patients $(\mathrm{P}$ ) with newly-diagnosed Type 1 (insulin-dependent) diabetes mellitus showing borderline titres or lacking IgM against $\mathrm{CBV}$

\begin{tabular}{|c|c|c|c|c|c|}
\hline \multirow{3}{*}{$\begin{array}{l}\text { Patients } \\
\text { and their } \\
\text { siblings }\end{array}$} & \multicolumn{5}{|c|}{ Serotype of CBV } \\
\hline & \multicolumn{2}{|c|}{ Definite titre } & \multicolumn{2}{|c|}{ Borderline titre } & \multirow{2}{*}{$\begin{array}{l}\text { Total IgM } \\
\text { positivity }\end{array}$} \\
\hline & $\mathrm{A}$ & $\mathrm{C}$ & $\bar{A}$ & $\mathrm{C}$ & \\
\hline $\begin{array}{c}\text { P17-1-F } \\
\text { S1-9-F }\end{array}$ & $\overline{2}, 4$ & - & - & 2,4 & $\overline{2}, 4$ \\
\hline $\begin{array}{l}\text { P 18-9-M } \\
\text { S 1-11-M }\end{array}$ & - & $\overline{4}$ & 4 & $\begin{array}{l}4 \\
-\end{array}$ & $\begin{array}{l}4 \\
4\end{array}$ \\
\hline $\begin{array}{r}\text { P 19-2-M } \\
\text { S1-6-F }\end{array}$ & - & $\overline{4}$ & $\begin{array}{l}4,5 \\
4\end{array}$ & - & $\begin{array}{l}4,5 \\
4\end{array}$ \\
\hline $\begin{array}{l}\text { P 20-9-F } \\
\text { S1-13-M }\end{array}$ & $\overline{4}$ & $\overrightarrow{\mathrm{NA}}$ & $\overline{1,2}$ & $\overline{\mathrm{NA}}$ & $-\overline{1,2,4}$ \\
\hline $\begin{array}{l}\text { P21-4-F } \\
\text { S 1-18-F } \\
\text { S 2-13-F }\end{array}$ & $\frac{-}{-}$ & $\begin{array}{l}- \\
\text { NA }\end{array}$ & $\begin{array}{r}4 \\
4 \\
-\end{array}$ & $\begin{array}{l}\text { NA } \\
\text { NA }\end{array}$ & $\begin{array}{l}4 \\
4 \\
4\end{array}$ \\
\hline $\begin{array}{r}\mathrm{P} 22-35 \\
\mathrm{~S} 1-16\end{array}$ & - & $\begin{array}{l}-, \mathrm{NA} \\
-, \mathrm{NA}\end{array}$ & - & - & - \\
\hline
\end{tabular}

A, acute specimen; C, convalescent specimen; NA, specimen not available; $M$, male; $F$, female; $P$, patient; $S$, sibling.

a The first numeral indicates the patients number and the second one, age.

The first numeral indicates the sibling's number and the second one, age.

Table 3. Summary of the results presented in Tables 1 and 2 showing the degree of similarity between the Type 1 (insulin-dependent) diabetic patients and their siblings regarding IgM positivity

\begin{tabular}{lll}
\hline $\begin{array}{l}\text { Degree of similarity } \\
\text { in IgM positivity }\end{array}$ & Number \\
\cline { 2 - 3 } & Definite titre & $\begin{array}{l}\text { IgM positivity } \\
\text { including } \\
\text { borderline titre }\end{array}$ \\
\hline $\begin{array}{l}\text { Patients and siblings showing } \\
\text { only homotypic IgM }\end{array}$ & 6 & 15 \\
$\begin{array}{l}\text { Patients and siblings showing } \\
\text { both homotypic and } \\
\text { heterotypic IgM }\end{array}$ & 4 & 10 \\
$\begin{array}{l}\text { Patients and siblings showing } \\
\text { only heterotypic IgM } \\
\begin{array}{l}\text { Patients and/or siblings lacking } \\
\text { IgM }\end{array}\end{array}$ & 1 & 2 \\
\hline
\end{tabular}

a indicates the number of observations. In cases where a Type 1 diabetic patient had more than one sibling, comparison was made with each sibling

off were considered, the number of siblings with ditypic responses increased to ten. In addition, one sibling now showed IgM against three serotypes. Thus far, 2-7 years after the investigation, no signs or symptoms of Type 1 diabetes have developed in any of the siblings.

\section{Comparison between patients and their siblings regarding IgM frequency and specificity}

As mentioned above, the frequency of CBV-IgM was high among both the patients and their siblings (Tables 1,2). With the high cut-off value, $16(46 \%)$ patients and 16 
(34\%) siblings were positive. There was no definite difference in titre levels between the patients and siblings. When the borderline titres were included, the IgM frequency increased in both groups. The number of patients showing CBV-IgM was then $19(54 \%)$ and that of siblings $29(62 \%)$.

The serotypes of CBV to which IgM was directed are seen in Tables 1 and 2. CBV 4 IgM was most frequent (in 11 patients and 16 siblings), followed by $\operatorname{IgM}$ against CBV 3 (eight patients and 11 siblings), CBV 2 (six patients and nine siblings), CBV 5 (six patients and four siblings) and CBV 1 (one patient and one sibling). IgM against the same serotype(s) was often observed in the same family. This similarity between the patients and their siblings markedly increased when borderline titres were included (Tables 1-3).

\section{Discussion}

The principal aim of this investigation was to determine whether the IgM responses detected in children with newly-diagnosed Type 1 diabetes are antibodies to CBV and not cross-reacting antibodies or antibodies induced by an unspecific polyclonal activation of lymphocytes. We have obtained strong evidence in this study that the antibodies measured are CBV-specific antibodies resulting from a recent or current infection. This is based on the fact that in most families the siblings showed a pattern of CBV antibodies similar to that in the diabetic patients. The use of the lower cut-off value increased the similarities in the IgM responses between the patients and their siblings. We claim that the lower cut-off value can be used in a study like this. However, even with the higher cut-off value the similarities in the CBV-IgM responses were striking. Several patients as well as siblings showed IgM against more than one serotype. It is impossible to say to' what extent cross-reactions or anamnestic responses may occur. Our RIAs of CBV-IgM with the use of the higher cut-off value have been found to be type-specific or narrow type-specific $[8,11,12]$. In this study most patients and their siblings showed IgM against the same serotype(s). It would therefore seem that very few results might be due to crossreactions or anamnestic responses, and the conclusions drawn concerning a recent or current infection in the patients and the spread to or from the siblings are in all probability correct.

IgM against CBV 4 was the antibody most frequently detected, and this serotype is the one most strongly associated with Type 1 diabetes in children. Some authors have proposed that not all strains of a certain serotype of CBV are diabetogenic and they suggest that this is the reason why more children in a family do not develop diabetes. It is highly probable that the individual Type 1 diabetic patient and his or her sibling(s) were infected with the same strain of CBV. It therefore seems, that other factors, not least the HLA pattern in the children, must be of importance for the development of Type 1 diabetes. In fact, the frequency of CBV-IgM has been found to be higher in diabetic children with HLA DR 3 and/or DR 4 than in those with other HLA DR patterns $[14,15]$.
There are mechanisms hypothesized by which CBV might cause Type 1 diabetes [16-18]. CBV might be able to kill the Beta cells directly during an acute infection. It is now well-known that CBV is also able to cause chronic infections. CBV might therefore be involved in the cases where the destruction of the Beta cells occurs over a longer period of time. Another mechanism may be that CBV causes alterations of the Beta cells which are recognized as foreign by the immune system. An autoimmune response could develop leading to the destruction of the Beta cells. This might also occur if antibodies induced by CBV react with human islet cell protein. The present study yields no information concerning the mechanisms involved.

As mentioned above, in most families the siblings were infected with the same serotype(s) as the patients. We did not find any definite differences between the patients and their siblings concerning the levels of the definite titres or the time of appearance of CBV-IgM. It is therefore impossible to say which of the children was infected first, the patient or the siblings. The intrafamilial spread of enteroviruses has previously been studied by means of isolation of virus and neutralization tests $[9,10]$. The results of these studies showed that the spread of Coxsackie viruses, including group A, within families is considerable, about $75 \%$ of exposed susceptible subjects becoming infected. In our study $54 \%$ of the patients and $62 \%$ of the siblings showed CBV-IgM.

Acknowledgements. We are grateful to Ms. M. Christensen, Mrs. N. Rosen and Ms. B. Westerberg for excellent technical assistance.

\section{References}

1. Gamble D, Kinsley M, Fitzgerald M, Bolton R, Taylor K (1969) Viral antibodies in diabetes mellitus. Br Med J 3: 627--630

2. Gamble D, Taylor K (1973) Coxsackie B virus and diabetes. $\mathrm{Br}$ Med J 1:289-290

3. Yoon J-W, Austin M, Duodera T, Notkins A (1979) Virus induced diabetes mellitus: isolation of virus from the pancreas of a child with diabetic ketoacidosis. N Engl. I Med 300: 1173-1179

4. Gladisch R, Hofmann W, Waldherr R (1976) Myocarditis und insulitis nach Coxsackievirus-infektion. Z Kardiol 65: 837-849

5. Barret-Conner E (1985) Is insulin-dependent diabetes mellitus caused by Coxsackie B infection? A review of the epidemiologic evidence. Rev Infect Dis 7: 207-215

6. King ML, Bidwell D, Shaikh A, Voller A, Banatvala JE (1983) Coxsackie-B-virus-specific IgM responses in children with insulin-dependent (juvenile-onset type I) diabetes mellitus. Lancet I: 1397-1399

7. Banatvala JE, Schernthaner G, Schober E et al. (1985) Coxsackie $B$, mumps, rubella and cytomegalovirus specific IgM responses in patients with juvenile-onset insulin-dependent diabetes mellitus in Britain, Austria, and Australia. Lancet I: 2409-2412

8. Tuvemo T, Frisk G, Friman G, Ludvigsson J, Diderholm H (1989) IgM against Coxsackie B viruses in children developing type I diabetes mellitus-A seven year retrospective study. Diab Res 9: 125-129

9. Gelfand H, Holguin A (1960) Enterovirus infection in healthy children. Arch Enviroment Health 5: 404-411

10. Kogon A, Spigland I, Frothingham E et al. (1969) The virus watch program: A continuing surveillance of viral infections in Metropolitan New York families. VII. Observations on viral ex- 
cretion, seroimmunity, intrafamilial spread and illness association in Coxsackie and Echo virus infections. Amer J Epidem 89: $51-61$

11. Torfason E, Frisk G, Diderholm H (1984) Indirect and reverse radioimmunoassays and their apparent specificities in the detection of antibodies to enteroviruses in human sera. J Med Virol 13: $13-31$

12. Frisk G, Torfason E, Diderholm H (1984) Reverse radioimmunoassays of $\operatorname{IgM}$ and $\operatorname{IgG}$ to Coxsackie B viruses in patients with acute myopericarditis. J Med Virol 14: 191-200

13. Frisk G, Nilsson E, Ehrnst A, Diderholm H (1989) Enterovirus IgM detection. Specificity of $\mu$ antibody-capture radioimmunoassays using virions and procapsids of Coxsackie $B$ virus as antigen. J Virol Meth 24: 191-202

14. Fohlman J, Böhme J, Rask L, Frisk G, Diderholm H, Friman G, Tuvemo T (1987) Matching of host genotype and serotypes of Coxsackie B virus in the development of juvenile diabetes. Scand J Immunol 26: 105-110

15. Schernthaner G, Banatvala JE, Scherbaum W et al. (1985) Coxsackie-B-virus-specific IgM responses, complement-fixing islet cell antibodies, HLA DR antigens, and C-peptide secretion in insulin-dependent diabetes mellitus. Lancet II: 630-632
16. Banavtvala J (1987) Insulin-dependent (juvenile-onset, Type I) diabetes mellitus Coxsackie B viruses revisited. Prog Med Virol 34: $33-54$

17. Craighead J, Huber S, Sriram S (1990) Animal models of Picornavirus-induced autoimmune disease: their poissible relevance to human disease. Lab Invest 63: 432-446

18. Toniolo A, Federico G, Basolos F, Onodera T (1988) Coxsackie viruses. A general update. In: Bendinelli M, Friedman $\mathrm{H}$ (eds) Diabetes mellitus, pp 351-382

Received: 5 March 1991

and in final revised form: 1 November 1991

Dr. G.Frisk

Department of Medical Virology

Biomedical Centre

Box 584

S-75123 Uppsala

Sweden 